\title{
The naturalized flora of Brazil: a step towards identifying future invasive non-native species
}

\author{
Rafael Dudeque Zenni ${ }^{1}$
}

\begin{abstract}
Human-mediated species introductions are one of the defining factors of the Anthropocene. Non-native species can form invasive populations that affect biodiversity, ecosystem services, or farming. Here I summarized data on naturalized vascular species from the Brazilian list of seed plants and tested the hypotheses that more populated regions and biomes with less remaining natural vegetation harbor more naturalized species. The Atlantic Forest had the largest number of naturalized species, whereas the Pampa had the highest proportion of naturalized species in relation to the biome's total richness. The number of naturalized species was affected both by human population size and proportion of remaining natural vegetation. Family Poaceae had the highest numbers of naturalized species in all biomes, and, together with Asteraceae and Fabaceae, forms the top three families in number of naturalized species in five of the biomes. There were no records of species naturalized in all six biomes. However, of the 46 species naturalized in five out of six biomes, half were Poaceae. The results indicate that the Brazilian flora is currently composed both by native and naturalized species. Assessments of invasion risks and of impacts by naturalized species could help set management priorities and resource allocation towards control. Key words: Alien species, early detection, invasion biology, nature conservation.
\end{abstract}

\begin{abstract}
Resumo
Introduções de espécies mediadas por humanos são um dos fatores determinantes do Antropoceno. Espécies exóticas podem formar populações invasoras que afetam a biodiversidade, serviços ecossistêmicos e agropecuária. Neste trabalho, eu avalio os dados sobre espécies naturalizadas no Brasil da lista de plantas com semente da flora do Brasil e testo as hipóteses de que regiões mais populosas e biomas com menor área natural remanescente contêm mais espécies naturalizadas. A Mata Atlântica teve o maior número de espécies naturalizadas, enquanto o Pampa teve a maior proporção de espécies naturalizadas em relação ao total de espécies no bioma. O número de espécies naturalizadas foi afetado tanto pelo número de habitantes quanto pela proporção de vegetação remanescente nos biomas. A família Poaceae conteve o maior número de espécies naturalizadas em todos os biomas e, junto com as famílias Asteraceae e Fabaceae, foram as três famílias com maior número de espécies naturalizadas em cinco biomas. Não houve registro de espécies naturalizadas em todos os seis biomas. Entretanto, das 46 espécies naturalizadas em cinco biomas, metade são Poaceae. Os resultados indicam que a flora brasileira é atualmente composta por espécies nativas e naturalizadas. Análises formais dos riscos de invasão biológica e potenciais impactos negativos causados por espécies naturalizadas devem ajudar na definição de prioridades de manejo e na alocação de recurso para controle.
\end{abstract}

Palavras-chave: Biologia de invasões, conservação da natureza, detecção precoce, espécies exóticas.

\section{Introduction}

Humans have been transporting species around the globe for centuries. Among the reasons for introducing species to regions where they did not occur previously are agriculture, agroforestry, forestry, forage, and horticulture (Zenni 2014). As a consequence, virtually all ecosystems in the world currently host non-native species (van Kleunen et al. 2015). Together with other drivers of global environmental change (i.e., climate change and land use transformation), human-mediated species introductions are one of the defining factors of the Anthropocene (Lewis \& Maslin 2015). A small proportion of the species introduced either with

${ }^{1}$ Universidade de Brasília, Inst. Ciências Biológicas, Campus Darcy Ribeiro, Asa Norte, bl. E, 70910-900, Brasilia, DF. rafaeldz@gmail.com 
intentional or accidental human assistance form invasive populations that threaten biodiversity, ecosystem services, and farming (Pyšek et al. 2012; Yelenik \& D'Antonio 2013). Some invasive species are known to have caused species extinctions, immense economic losses, and losses of important crops around the world (Simberloff 2013). Thus, it is pivotal to understand the patterns and drivers of species naturalizations and invasions in order to prevent and reduce the negative impacts caused by biological invasions.

A biological invasion is a populationlevel process often defined as the introductionnaturalization-invasion continuum (Blackburn et al. 2011). Briefly, an organism which survives transport is successfully introduced into a region where it did not occur previously (i.e., non-native species), reaches reproductive age, produces descendants to form a viable self-sustaining population (i.e., naturalized species), and spreads over considerable distances from the point of introduction in a short period of time, often achieving high population densities (i.e., invasive species). For instance, for woody plants it was suggested that a population spreading $100 \mathrm{~m}$ away from the point of introduction in less than 50 years could be considered a biological invasion (Richardson et al. 2000). Only a fraction of the non-native species form naturalized populations, and only a small subset of these result in invasions. Communities containing a combination of native and naturalized species are the new norm in most ecosystems (van Kleunen et al. 2015) and some of these naturalized populations will eventually invade. Thus, although biological invasions are considered an improbable result of species introductions, when it does happen it may cause dramatic changes in native communities and ecosystems and reach massive proportions (Wardle et al. 2011). From a management point of view, it is always preferable to prevent invasions from happening or controlling them no later than just after the naturalization stage, when populations are often restricted to well-delimited areas.

The Brazilian List of seed plants (BFG 2015) identified 32,634 vascular species in Brazil, of which 525 were naturalized non-native species. The inventory revealed that the Atlantic Forest is the richest biome with 15,001 native species, followed by the Cerrado (12,097 native species), the Amazon $(11,896)$, the Caatinga $(4,657)$, the Pampa $(1,685)$, and the Pantanal $(1,277)$. However, analyses of numbers, types, and proportions of naturalized species in Brazil were lacking. In this study, I aimed to (i) summarize the data on naturalized species available in the inventory of Brazilian seed plants and (ii) to test the hypotheses that biomes with more people and less remaining natural vegetation cover of Brazil harbor more naturalized species.

\section{Material and Methods}

Data were gathered from BFG (2015), Costa \& Peralta (2015), Maia et al. (2015), Menezes et al. (2015) and Prado et al. (2015). A detailed description of how the list was compiled and curated is available in BFG (2015). I kept only vascular plant species with accepted names, known to be present in Brazil, and with known origin (i.e., native, naturalized, or cultivated). Avascular plants were removed because data on these groups were limited to a few regions and knowledge regarding the actual origin of many avascular plants is not available. From those species, I prepared a list of States, regions, terrestrial biomes (Atlantic Forest, Amazon, Caatinga, Cerrado, Pampa, and Pantanal), and vegetation types (phytophysiognomies) where they were reported to occur. I also obtained the percentage of remaining natural vegetation cover for each biome from the Brazilian Biomes Project (Projeto biomas do Brasil 2015). Finally, I gathered data on the States' total areas, States' urban areas, and human population per biome from the Brazilian Institute of Geography and Statistics (IBGE 2015). All the IBGE data are for the year 2009 and were the most recent available. I calculated the proportion of naturalized species in each biome by dividing the number of naturalized species by the sum of all species known to occur in the biome (native, cultivated, and naturalized).

To test the associations between number of naturalized species per biome and human population size, percentage of remaining natural vegetation cover, and number of native species, I used generalized linear models (GLM) with Poisson error distribution $(\alpha=0.05)$. I also tested the associations between number of naturalized species and the proportion of urban area per State. State or biome total area was added to all models as a covariate to check whether results were scale dependent. I tested both biome and State level metrics in order to obtain two independent confirmations of the hypotheses that naturalized species richness is associated to human population and to conversion of natural areas to areas of 
intensive use (i.e., urban, agriculture, and pastures). Lastly, I used a chi-square test to see if native and naturalized species were equally frequent in anthropogenic areas (e.g., degraded areas).

\section{Results}

There were a total 525 non-native naturalized vascular plant species in the inventory of Brazilian plants (Appendix 1). The Atlantic Forest biome had the highest number of naturalized species $(n=416)$, followed by the Cerrado $(\mathrm{n}=223)$, the Amazon $(\mathrm{n}=184)$, the Caatinga $(\mathrm{n}=155)$, the Pampa $(\mathrm{n}=$ 114), and the Pantanal $(n=39)$ (Fig. 1a). In terms of proportional representation, the Pampa had the highest number of non-native naturalized species per total species richness $(6.8 \%)$, followed by the Caatinga (3.4\%) and the Pantanal (3.6\%), the Atlantic Forest (2.7\%), the Cerrado (1.9\%), and the Amazon (1.5\%) (Fig. 1b).

The number of naturalized species in a biome was positively associated with human population size $(\mathrm{z}=2.3, \mathrm{p}=0.02$; Fig. $2 \mathrm{a})$ and was not affected by biome total area $(\mathrm{z}=1.8, \mathrm{p}=0.08)$. Also, the number of naturalized species in a given biome was negatively associated with the proportion of remaining natural vegetation cover $(\mathrm{z}=-9.2, \mathrm{p}<0.001$; Fig. $2 \mathrm{~b}$ ). Less remaining natural vegetation meant more naturalized species. Further, the number of native species in a biome predicted the number of non-native naturalized species ( $\mathrm{z}=11.7, \mathrm{p}<0.001$; Fig. 3 ); more native species meant more naturalized species. However, in these two previous cases, the interaction term with biome total area was also significant $(\mathrm{z}=-3.7$ and $\mathrm{z}=-3.8$, respectively, $\mathrm{p}<0.001$ ). As a consequence, it is not possible to evaluate the sole role of remaining natural vegetation in naturalized species richness and biome size must be taken into consideration. Removing outliers did not change the results of the tests.

When looking at the State level, I found patterns similar to those of the analyses with biomes. States with larger urban areas harbour more naturalized species $(\mathrm{z}=10.6, \mathrm{p}<0.001)$ and this effect was independent of State size $(\mathrm{z}=0.3$, $\mathrm{p}=0.76$ ). Likewise, States with larger population sizes also had more naturalized species $(\mathrm{z}=9.74$, $\mathrm{p}<0.001)$. Again, the effect was independent of State size $(\mathrm{z}=-0.9, \mathrm{p}=0.2)$. São Paulo had the largest number of naturalized species $(\mathrm{n}=332)$, followed by Paraná $(n=270)$, Minas Gerais $(n=263)$, Santa Catarina $(\mathrm{n}=260)$, and Rio Grande do Sul $(\mathrm{n}=255)$.
Non-native species were more likely to be recorded occurring in disturbed areas than native species $\left(\chi^{2}=4.39, \mathrm{p}<0.001\right)$. While $71.05 \%(\mathrm{n}=373)$ of the naturalized species were reported to occur in disturbed areas, only $6.46 \%(n=2,042)$ of the native species occurred in these habitats. The remaining naturalized species $(n=124)$ were only recorded occurring in natural areas or had no specific habitat associated to them $(\mathrm{n}=28)$. By definition
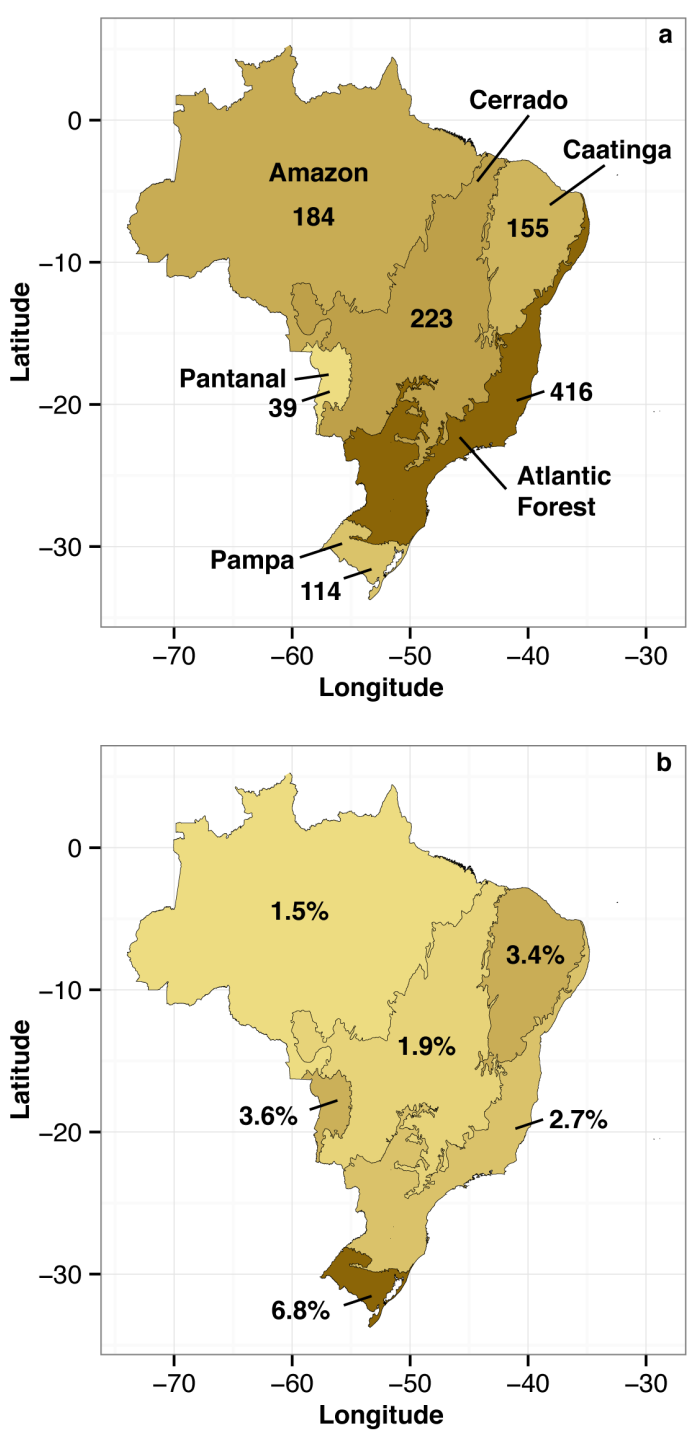

Figure 1 - a. Number of non-native naturalized plant species; $b$. proportion of non-native naturalized plant species present across six terrestrial biomes and two aquatic regions in Brazil. Lighter shades represent lower numbers and proportions, whereas darker shades depict higher numbers and proportions. 
Table 1 - The three families with the highest numbers of non-native naturalized species per biome, the number of species in each family that are naturalized in each biome and the proportion of naturalized species in each biome that belong to the family.

\begin{tabular}{llll}
\hline Biome & Family & Number of naturalized species & \% \\
\hline Atlantic Forest & Poaceae & 112 & 26.9 \\
& Asteraceae & 31 & 7.4 \\
Cerrado & Fabaceae & 26 & 6.2 \\
& Poaceae & 73 & 32.7 \\
& Asteraceae & 24 & 10.8 \\
Amazon & Fabaceae & 21 & 9.4 \\
& Poaceae & 55 & 29.9 \\
Caatinga & Fabaceae & 21 & 11.4 \\
& Asteraceae & 13 & 7.1 \\
Pampa & Poaceae & 54 & 34.8 \\
& Fabaceae & 14 & 9.0 \\
& Amaranthaceae & 9 & 5.8 \\
Pantanal & Poaceae & 34 & 29.8 \\
& Caryophyllaceae & 23 & 20.2 \\
& Asteraceae & 20 & 17.5 \\
& Poaceae & 17 & 43.6 \\
& Fabaceae & 5 & 12.8 \\
& Asteraceae & 4 & 10.3 \\
\hline
\end{tabular}

(i.e., Blackburn et al. 2011), it is probable the 124 records of non-native species in natural habitats were records of invasion rather than naturalization.

The family Poaceae had the largest number of naturalized species in all six biomes (Tab. 1). The families Asteraceae and Fabaceae were among the top three families in number of naturalized species in five out of the six terrestrial biomes, albeit not in the same ones. Those three families were the three richer ones in the Amazon, the Atlantic Forest, the Cerrado, and the Pantanal biomes. In the Caatinga, the family Amaranthaceae was the third in species richness after Poaceae and Fabaceae. And in the Pampa biome the family Caryophyllaceae was the second richest after Poaceae, before Asteraceae (Tab. 1).

None of the 525 species were naturalized in all six biomes. However, of the 46 non-native species that were naturalized in five biomes, half were grasses (Poaceae). The remaining species belonged to 14 different families. Another 52 species were present across four terrestrial biomes, of which 19 species belong to the Poaceae family and the remaining species are contained in 18 different families. Thus, a single family (Poaceae) made up to $43 \%$ of all non-native species naturalized in more than half of the Brazilian terrestrial biomes.

\section{Discussion}

Based on the data gathered by the Brazilian Flora Group (BFG 2015), the hypotheses that more populated and more deforested biomes of Brazil harbour more naturalized species were supported. The results also supported the idea that habitats that support a high diversity of native species also tend to support a high diversity of non-native species (Fig. 3). The Poaceae family was disproportionally overrepresented in the non-native naturalized flora, having the highest overall richness among all naturalized species $(n=142)$ and the most widespread species (23 species naturalized across 5 biomes). The Poaceae family was also overrepresented among invasive non-native species in Brazil (Zenni \& Ziller 2011), especially the African C-4 grasses (Zenni 2014). African grasses are known to benefit from 

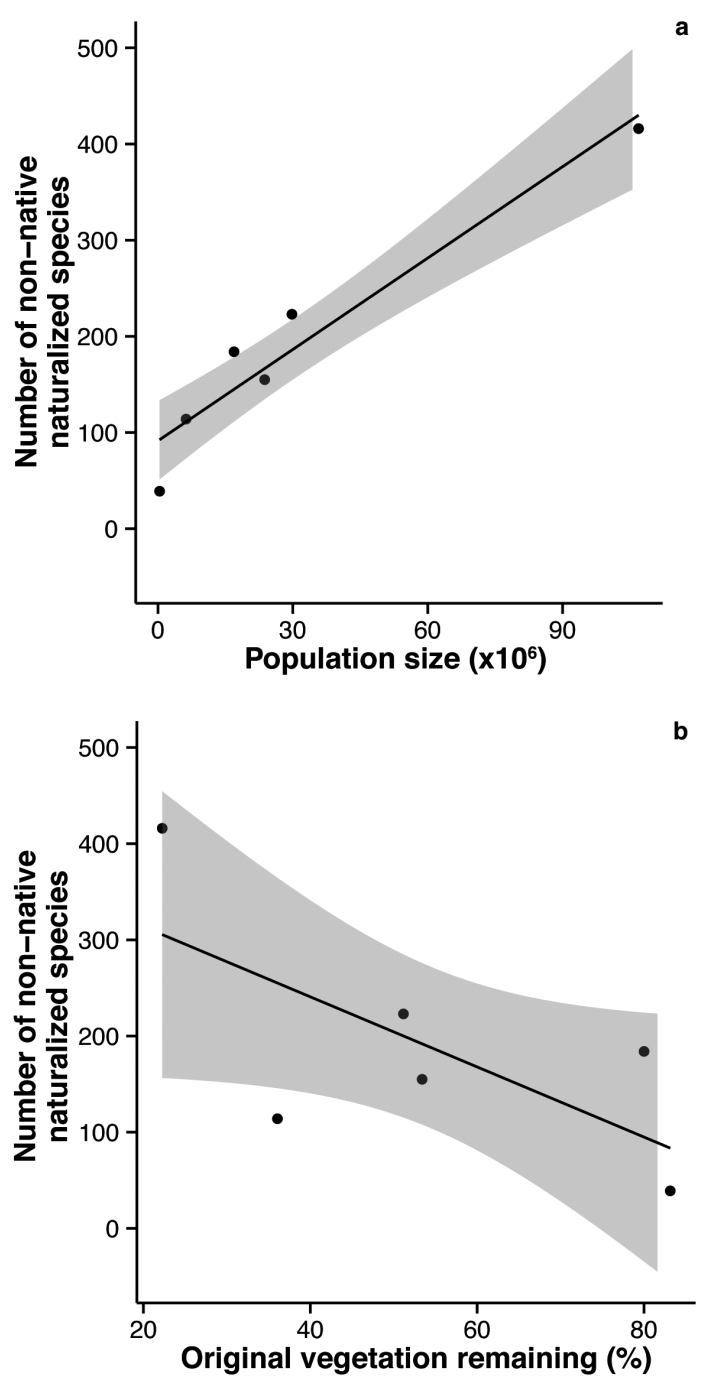

Figure 2 - Relationship between number of non-native naturalized plant species in the Brazilian Biomes and a. human population in each biome; b. percentage of the native biome habitats remaining (areas not converted for human intensive use). Solid lines represent generalized linear model fittings and grey shades are $\pm 95 \%$ confidence intervals. The outlier in (a) did not change model fitting.

anthropogenic disturbances, thus it comes as no surprise that grasses were the most abundant group of naturalized plants in a scenario where the naturalization of non-native species is both directly and indirectly related to human population, urbanization, and habitat degradation.

The results make it clear that a significant part of the Brazilian flora is now composed of introduced species forming self-sustaining populations. While the Atlantic Forest had the richest non-native naturalized flora, the Pampa had the highest proportion of naturalized species. Given that native and naturalized species richness were correlated (Fig. 3), it is unclear which one of the two metrics better reflect the current magnitude of species naturalization in the biomes. I suggest considering both (richness and proportion) in subsequent analyses. Although naturalized species richness was associated with human-induced disturbances, previous work has shown that nonnative species are also widespread in Brazilian natural and protected areas (Sampaio \& Schmidt 2013; Ziller \& Dechoum 2013). Ecologists, managers, and policy makers need a better understanding of the role non-native species have in natural ecosystems.

The inventory of the Brazilian Flora did not point out which of the naturalized species are known to have invasive populations, and the available data on invasive alien plants in Brazil were gathered using different criteria. Thus, it is unclear which naturalized species became invasive in the different biomes and regions. Previous research identified at least 180 invasive alien plants in Brazil (Sampaio \& Schmidt 2013; Ziller \& Dechoum 2013; Zenni \& Ziller 2011), but only $40 \%(n=73)$ of these invasive non-native species were also listed in the inventory of the Brazilian flora. The remaining 107 non-native species considered invasive somewhere in Brazil were absent from the inventory. For instance, the inventory of Brazilian seed plants used in this study did not include any of the five Acacia Mill. species (Fabaceae) which are currently being cultivated and shown to be naturalized (Attias et al. 2013). When considering only the invasive non-native species that were included in the inventory, $13.4 \%$ of the naturalized species in Brazil have already crossed the naturalization stage and become invasive. Because of these discrepancies, it is unclear how underestimated the inventory of the Brazilian flora is regarding non-native species and if datasets on invasive species are overestimated. Future updates of the Brazilian List should try to address the current gap in Brazilian non-native flora.

Naturalization is a required intermediate stage towards biological invasion (Blackburn et al. 2011). While some naturalized populations may never turn into invasive populations, others will. Thus, non-native naturalized populations 


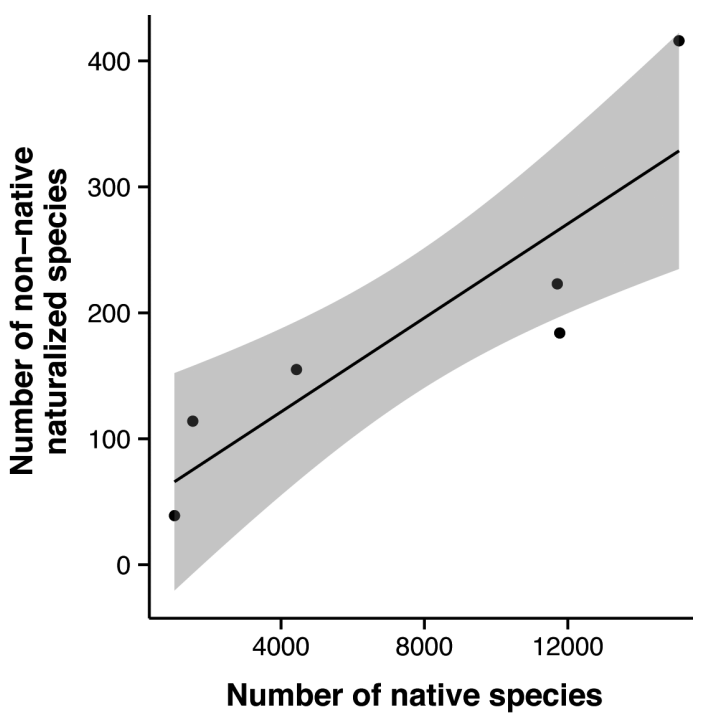

Figure 3 - Relationship between number of native species and number of naturalized species in Brazilian Biomes. The solid line represents the GLM fit and grey shades represent $\pm 95 \%$ confidence intervals.

and species that are not invading should be prioritized for research and management efforts regarding potential invasion and impact on native ecosystems. For instance, the Amazon biome has $80 \%$ of its natural area remaining, has the third highest number of naturalized species, but has the lowest number of invasive species (Zenni \& Dechoum 2013). Inversely, the Atlantic Forest is the most degraded biome, and has both the highest numbers of naturalized and invasive species. These two opposite scenarios provide important insights for dealing with biological invasions. First, the current condition of the Atlantic Forest suggests what may happen in the Amazon and other biomes if managers and policy makers do not take action. Second, different regions of Brazil may require different strategies regarding non-native species; for instance, while in the Amazon the focus should be on prevention and early detection of invasive non-native species, in the Atlantic Forest the focus should be on containment and reduction of invaded areas, and on ecological restoration. Whenever possible, especially regarding protected areas, naturalized populations posing high invasion risk should be excluded before they invade. By understanding the current status of naturalized species in different habitats and the drivers of naturalization (i.e., which species are naturalized, and where the naturalized populations are), managers and policy makers can identify priorities and allocate resources wisely to prevent spread and potential negative impacts.

The focus of the Brazilian list of seed plants was to catalogue the native flora of Brazil (BFG 2015), and the initiative to include nonnative species (cultivated and naturalized) could be considered a parallel effort. Also, inclusion of species in the list depended on herbarium vouchers, but not all botanists include non-native plants in their samplings and many ecologists working on non-native plants do not make herbarium deposits of study species. The lack of herbarium vouchers seems to be especially true for non-native species that are neither naturalized nor invasive (e.g., cultivated). The existing gap between the list of Brazilian seed plants and several published lists of invasive plants attests to that fact. Consequently, the current list of naturalized species in Brazil and the estimates I obtained for numbers and proportions of species may be considered conservative estimates. Another limitation of this study is that species that are native to some Brazilian biome or vegetation type, but are naturalized in another biome or vegetation type were not considered by the group of researchers that compiled the Brazilian list. For instance, Schyzolobium parahyba (Vell.) S.F.Blake is native to the Atlantic Coastal Rainforest, but became invasive in Seasonally Semi-deciduous Forests (both are part of the Atlantic Forest biome) after human-mediated introduction (Abreu et al. 2014). Given that species ranges are a biogeographical concept rather than a geopolitical one, care should be taken when interpreting statements of species as native or non-native to Brazil. Also, botanists should be considerate of inter-habitat, but intranational, species introductions.

In conclusion, the current study presents the first nationwide assessment of the naturalized flora of Brazil and conveys important knowledge for research and conservation prioritization. It was made evident that non-native species are widespread in all Brazilian biomes and regions. Human presence, and human actions and activities, are an important reason for the observed patterns of non-native species naturalization. Research and conservation actions could greatly benefit from the integration among databases of native and nonnative species in Brazil regardless of the statuses of populations. To improve the record of non-native 

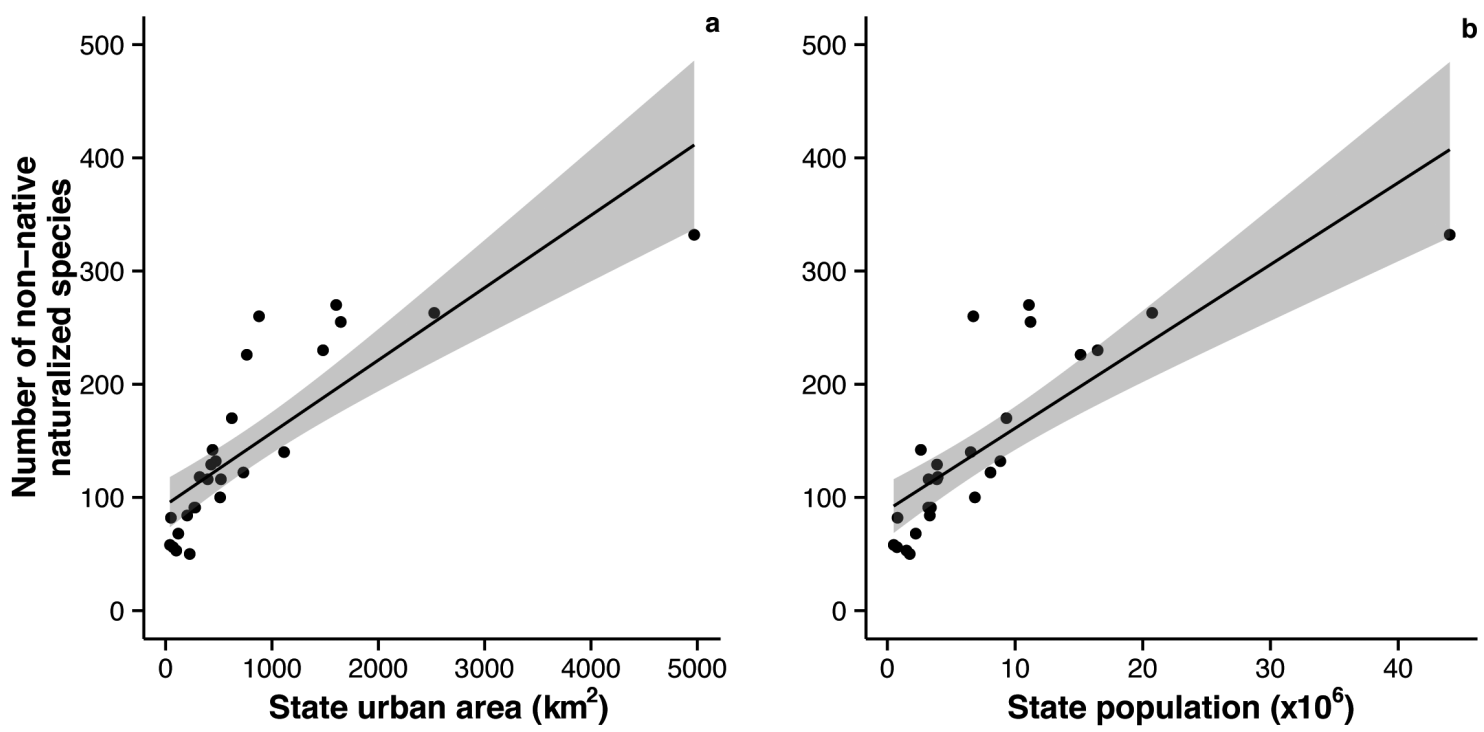

Figure 4 - Relationship between number of naturalized plant species in Brazilian States and (a) State urban area $\left(\mathrm{km}^{2}\right)$, and (b) human population size. Solid lines represent generalized linear model fittings and grey shades are $\pm 95 \%$ confidence intervals. The outliers did not change model statistical significance.

species, researchers and managers working on invasive non-native species should make an effort to improve the herbarium record on non-native species. Finally, formal assessments of invasion risks and of negative impacts caused by the species identified as already naturalized could help setting management priorities and resource allocation.

\section{Acknowledgements}

I thank Dr. Michele Dechoum and Daniela Zappi for comments that helped to improve the manuscript. This work would not have been possible without the collective effort of the Brazilian Flora Group in gathering, curating, and sharing the data on plant species in Brazil. RDZ is supported by CNPq-Brazil (Grant 400196/2014-0).

\section{References}

Abreu, R.C.R.; Santos, F.F.M. \& Durigan, G. 2014.

Changes in plant community of seasonally semideciduous forest after invasion by Schizolobium parahyba at southeastern Brazil. Acta Oecologica 54:57-64.

Attias, N.; Siqueira, M.F. \& Bergallo, H.G. 2013. Acácias australianas no Brasil: histórico, formas de uso e potencial de invasão. Biodiversidade Brasileira 3:74-96.

BFG. 2015. Growing knowledge: an overview of Seed Plant diversity in Brazil. Rodriguésia 66: 1085-1113. Blackburn, T.M.; Pyšek, P.; Bacher, S.; Carlton,
J.T.; Duncan, R.P.; Jarošík, V.; Wilson J.R.U. \& Richardson D.M. 2011. A proposed unified framework for biological invasions. Trends in Ecology \& Evolution 26:333-339.

Costa, D.P. \& Peralta, D.F. 2015. Bryophytes diversity in Brazil Rodriguésia 66: 1063-1071.

IBGE. 2015. Instituto Brasileiro de Geografia e Estatística. Availeble at <http://www.ibge.gov.br/ home/>. Access on 3 September 2015.

Lewis, SL \& Maslin, MA. 2015. Defining the anthropocene. Nature 519:171-180.

Projeto Biomas do Brasil. 2015. Biomas do Brasil. Available at $<$ http://www.projetobiomas.com.br $>$. Access on 3 September 2015.

Maia, L.C.; Carvalho Júnior, A.A.; Cavalcanti, L.H.; Gugliotta, A.M.; Drechsler-Santos, E.R.; Santiago, A.L.M.A.; Cáceres, M.E.S.; Gibertoni, T.B.; Aptroot, A.; Giachini, A.J.; Soares, A.M.S.; Silva, A.C.G.; Magnago, A.C.; Goto, B.T.; Lira, C.R.S.; Montoya, C.A.S.; Pires-Zottarelli, C.L.A.; Silva, D.K.A.; Soares, D.J.; Rezende, D.H.C.; Luz, E.D.M.N.; Gumboski, E.L.; Wartchow, F.; Karstedt, F.; Freire, F.M.; Coutinho, F.P.; Melo, G.S.N.; Sotão, H.M.P.; Baseia, I.G.; Pereira, J.; Oliveira, J.J.S.; Souza, J.F.; Bezerra, J.L.; Araujo Neta, L.S.; Pfenning, L.H.; Gusmão, L.F.P.; Neves, M.A.; Capelari, M.; Jaeger, M.C.W.; Pulgarín, M.P.; Menolli Junior, N.; Medeiros, P.S.; Friedrich, R.C.S.; Chikowski, R.S.; Pires, R.M.; Melo, R.F.; Silveira, R.M.B.; Urrea-Valencia, S.; Cortez, V.G. \& Silva, V.F. 2015. Diversity of Brazilian Fungi. Rodriguésia 66: 1033-1045. 
Menezes, M.; Bicudo, C.E.M.; Moura, C.W.N.; Alves, A.M.; Santos, A.A.; Pedrini, A.G.; Araújo, A.; Tucci, A.; Fajar,A.; Malone, C.; Kano, C.H.; Sant'Anna, C.L.; Branco, C.Z.; Odebrecht, C.; Peres, C.K.; Neuhaus, E.B.; Eskinazi-Leça, E.; Aquino, E.; Nauer, F.; Santos, G.N.; Amado Filho, G.M.; Lyra, G.M.; Borges, G.C.P.; Costa, I.O.; Nogueira, I.S.; Oliveira, I.B.; Paula, J.C.; Nunes, J.M.C.; Lima, J.C.; Santos, K.R.S.; Ferreira, L.C.; Gestinari, L.M.S.; Cardoso, L.S.; Figueiredo, M.A.O.; Silva, M.H.; Barreto, M.B.B.B.; Henriques, M.C.O.; Cunha, M.G.G.S.; Bandeira-Pedrosa, M.E.; Oliveira-Carvalho, M.F.; Széchy, M.T.M.; Azevedo, M.T.P.; Oliveira, M.C.; Cabezudo, M.M.; Santiago, M.F.; Bergesh, M.; Fujii, M.T.; Bueno, N.C.; Necchi Jr., O.; Jesus, P.B.; Bahia, R.G.; Khader, S.; Alves-daSilva, S.M.; Guimarães, S.M.P.B.; Pereira, S.M.B.; Caires, T.A.; Meurer, T.; Cassano, V.; Werner, V.R.; Gama Jr., W.A. \& da Silva, W.J. Update of the Brazilian floristic list of Algae and Cyanobacteria. Rodriguésia 66: 1047-1062.

Prado, J.; Sylvestre, L.S.; Labiak, P.H.; Windisch, P.G.; Salino, A.; Barros, I.C.L.; Hirai, R.Y.; Almeida, T.E.; Santiago, A.C.P.; Kieling-Rubio, M.A.; Pereira,A.F.N.; Øllgaard, B.; Ramos, C.G.V.; Mickel, J.T.; Dittrich, V.A.O.; Mynssen, C.M.; Schwartsburd, P.B.; Condack, J.P.S.; Pereira, J.B.S.\& Matos, F.B. Diversity of ferns and lycophytes in Brazil. Rodriguésia 66: 1073-1083.

Pyšek, P.; Jarošík, V.; Hulme, P.E.; Pergl, J.; Hejda, M.; Schaffner, U. \& Vilà, M. 2012. A global assessment of invasive plant impacts on resident species, communities and ecosystems: the interaction of impact measures, invading species' traits and environment. Global Change Biology 18:1725-1737.

Richardson, D.M.; Pyšek, P.; Rejmánek, M.; Barbour, M.G.; Panetta, F. D. \& West, C.J. 2000. Naturalization and invasion of alien plants: concepts and definitions. Diversity and Distributions 6: 93-107.
Sampaio, A.B. \& Schmidt, I.B. 2013. Espécies exóticas invasoras em unidades de conservação federais do Brasil. Biodiversidade Brasileira 3:32-49.

Simberloff, D. 2013. Invasive species: what everyone needs to know. 1ed. Oxford University Press, New York. 329p.

van Kleunen, M.; Dawson, W.; Essl, F.; Pergl, J.; Winter, M.; Weber, E.; Kreft, H.; Weigelt, P.; Kartesz, J.; Nishino, M.; Antonova, L.A.; Barcelona, J.F.; Cabezas, F.J.; Cardenas, D.; Cardenas-Toro, J.; Castano, N.; Chacon, E.; Chatelain, C.; Ebel, A.L.; Figueiredo, E.; Fuentes, N.; Groom, Q.J.; Henderson, L.; Inderjit; Kupriyanov, A.; Masciadri, S.; Meerman, J.; Morozova, O.; Moser, D.; Nickrent, D.L.; Patzelt, A.; Pelser, P.B.; Baptiste, M.P.; Poopath, M.; Schulze, M.; Seebens, H.; Shu, W.s.; Thomas, J.; Velayos, M.; Wieringa, J. J. \& Pysek, P. 2015. Global exchange and accumulation of non-native plants. Nature 525:100-103.

Wardle, D.A.; Bardgett, R.D.; Callaway, R.M. \& Van der Putten, W.H. 2011. Terrestrial ecosystem responses to species gains and losses. Science 332:1273-1277.

Yelenik, S.G. \& D'Antonio, C.M. 2013. Self-reinforcing impacts of plant invasions change over time. Nature 503: 517-520.

Zenni, R.D. \& Ziller, S.R. 2011. An overview of invasive plants in Brazil. Brazilian Journal of Botany 34:431-446.

Zenni, R.D. \& Dechoum, M.S. 2013. Paisagens antropizadas e invasão por plantas exóticas. In: Peres, C.A; Barlow, J.; Gardner, T.A. \& Vieira, I.C.G. Conservação da biodiversidade em paisagens antropizadas do Brasil. Editora UFPR, Curitiba. Pp. 549-563.

Zenni, R.D. 2014. Analysis of introduction history of invasive plants in Brazil reveals patterns of association between biogeographical origin and reason for introduction. Austral Ecology 39:401-407.

Ziller, S.R. \& Dechoum, M.S. 2013. Plantas e vertebrados exóticos invasores em unidades de conservação no Brasil. Biodiversidade Brasileira 3:4-31. 